\title{
Concession use to improve the housing and communal services efficiency
}

\author{
Sergey Yekimov ${ }^{1 *}$ and Viktoriia Nianko $^{2}$ \\ ${ }^{1}$ Publishing House "Education and Science", 18100, Praha, Czech Republic \\ ${ }^{2}$ Dniprovsk State Technical University, 51918, Dnipropetrovsk region, Kamianske, Ukraine
}

\begin{abstract}
Among the main reasons hindering the housing and communal complex development in Ukraine are the physically and morally outdated material and technical base, inefficient management structure and a significant share of state ownership. The lack of proper control over the tariff policy and the high cost of production make it necessary to find the new approaches to solving the problems related to the housing and communal services functioning. Attracting private investors to the housing and communal services makes it possible to reduce the financial burden on the budget, and also gives a possibility to make the enterprises that make up the housing and communal services profitable and ensure the provision of proper quality public services. Transfer use of housing and communal services enterprises to the concession management is a fairly effective form of public-private cooperation in this area. Housing and communal services are an important tool for improving the living standards of the population. Ensuring the housing and communal services efficiency growth is possible only if it is technically modernized. The solution to this problem can be achieved by attracting private investors to the industry, at the same time, the state should provide favorable conditions for these investors.
\end{abstract}

\section{Introduction}

Housing and communal services can rightly be considered one of the most important economy sectors. The success of its functioning largely depends on the population life quality level and the successful functioning of enterprises and organizations. Housing and communal services, in our opinion, affect the interests of State authorities, cultural and health institutions, enterprises and the population.

In the opinion of [1] housing and communal services is a complex of commercial farm units, services and enterprises of various forms of ownership which activities are aimed at providing convenient, safe and comfortable living of the citizens and the functioning of enterprises through the provision of public resources.

Housing and communal services in Ukraine have a number of specific features:

1. State ownership of infrastructure facilities, private ownership of residential premises and collective ownership of places in common use.

\footnotetext{
*Corresponding author: 3701313@mail.ru
} 
2. The quality of public services provided to the population is not always adequate to the prices for these services.

3. Housing and communal services can be classified as public and private goods.

According to [2] as a part of the housing and communal services the commercial farm units include the following service providers (Figure 1):

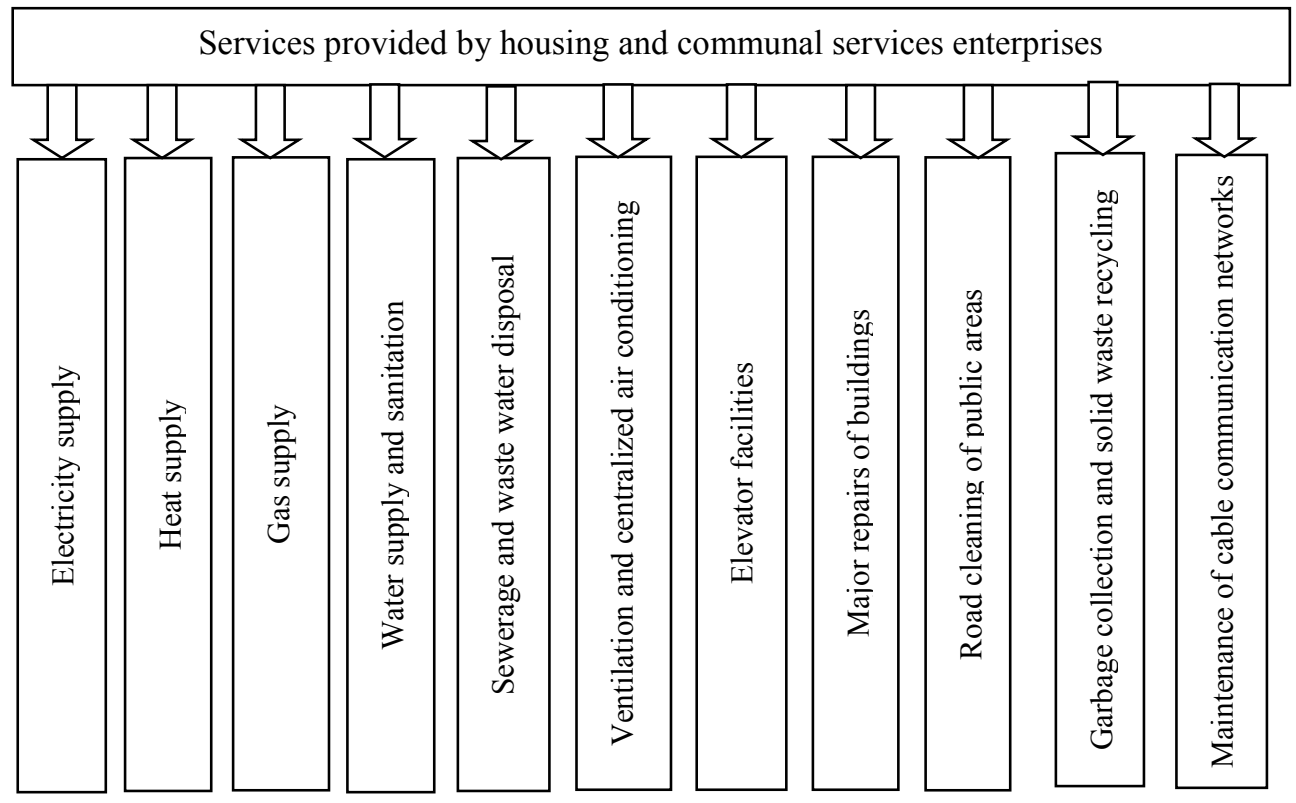

Fig. 1. Services provided by housing and communal services enterprises

In the opinion of [3] an important indicator of the population life quality is the provision of high-quality housing and communal services.

Housing and communal services create the conditions necessary for a favorable life of human society and are responsible for the successful functioning of the settlements' social and industrial infrastructure.

In the opinion of [4] the degree of citizens' satisfaction with the standard of living and the socio-political mood depends on the housing and communal services' quality. In this regard, providing the population with high-quality housing and communal services for public authorities is important.

In the opinion of $[5,6]$ the human development index largely depends on the quality of housing and communal services.

According to [6-8] housing and communal services have a great impact on the qualityof-life standards of the citizens, the economic and social potential of society, the investment attractiveness of the locality and the way of population life.

Housing and communal services is one of the most important sectors of the Ukrainian economy. In previous years, the housing and communal services were largely supported on the basis of state subsidies. This made it possible to restrain the prices for housing and communal services. However, due to the reduction in budget funding and the implemented price liberalization, the housing and communal services sector found itself in a difficult situation.

In our opinion, the main reasons that contributed to the crisis situation in the housing and communal services are inefficient tariff, urban planning and housing policies. 
According to [9] approximately $70 \%$ of the available housing stock of Ukrainian cities are the houses with low energy efficiency. The consumption of hot and cold water exceeds 1.5-2 times the indicators of industrialized countries.

Thus, a situation of social and economic imbalance in the field of housing and communal services has been created.

This requires the development and practical implementation of new approaches to ensuring the functioning of housing and communal services.

\section{Methods}

In the course of this work, we used an analytical method, which allowed us to study the problems considered in the work in their development and unity.

Taking into account the tasks and goals of this scientific research, the authors used the structural and functional method of scientific cognition.

As a result, it became possible to study a number of problems related to the use of the concession to improve the housing and communal services efficiency.

\section{Results}

Housing and communal services are of great social importance, they provide enterprises and population with the necessary utilities for their life, and therefore, they pay great attention to the level of the citizens' well-being and the economic development of Ukraine.

Currently, the main sources from which housing and communal services are financed are state subsidies and payment of consumers for the utilities provided to them. In our opinion, it is very important to reduce the burden on the budget and at the same time increase the housing and communal services sector efficiency. This can be achieved by attracting private investors by transferring housing and communal services enterprises to a concession.

For private investors, housing and communal services can be an interesting object for investment due to the following reasons:

1) Enterprises of the housing and communal services sector, as a rule, are the monopolists and therefore the implementation of the services produced by them is not associated with special difficulties.

2) Currently, most solid household waste is not recycled, incinerated or simply stored, polluting the environment. At the same time, the processing of solid household waste depends on the possibility of recycling their components.

3) Cost reduction due to the introduction of innovations in technological processes by housing and communal services enterprises will allow its investors to receive additional profit.

At the same time, the concession does not require the investor to spend money on the housing and communal infrastructure creation, but can use the existing one.

However, it should be noted that there are a number of problems that private investors may face when investing in the housing and utilities sector.

1) The low solvency level of a significant part of the Ukrainian population.

2) The availability of various benefits for the payment of utilities provided to certain categories of the population.

3) Lack of guarantees of the invested funds return by the private investor in case of disagreements with local authorities.

4) Difficulties in collecting debts for the utilities rendered, but not paid for by the consumers. 
5) The presence of monopolists among the housing and communal services suppliers, for example, this applies to the supply of water, natural gas and electricity.

At the same time, the transfer to a concession is a widespread way of housing and communal services enterprises functioning in foreign practice.

The concession can be one of the ways to attract private investment in housing and communal services, allowing to solve many social problems of the settlements. It can assist in the technical re-equipment of housing and communal services.

We adhere to the point of view that the transfer of housing and communal services to the concession should take place only on a competitive basis.

The reason for writing this research paper was the appeal to us of the local government representatives of the city Podhorodne, Dnipropetrovsk region. In the city the municipal enterprise has been engaged in the export of solid household waste for a long time.

The city residents put solid household waste in metal or plastic containers, and the company collected this waste according to the established schedule and took it out of the city to a landfill. The tariff for the removal of solid household waste was determined based on the volume of waste removed.

However, over time, the number of the city residents increased and the amount of solid household waste increased. The landfill was already almost completely filled and a new landfill was needed. In this regard, the representatives of local self-government suggested that local residents sort solid household waste, but the company that carries out the export of this waste has set tariffs for the export of sorted household waste the same as for nonsorted ones. Although many residents of the city supported the idea of sorting solid household waste, it did not have much effect.

Before the start of the study, a survey for the city residents had been conducted, the majority of respondents noted that they agree to sort solid household waste if they are paid for it or reduce the fee for the removal of this waste. The municipal enterprise, which was engaged in waste removal, did not reduce tariffs, explaining that their costs have increased since now it is necessary to go to consumers more times for different types of sorted garbage separately, and the material and technical base of this enterprise has remained the same. The city was unable to purchase vehicles for the transport of various types of solid waste.

We proposed to transfer the municipal enterprise for garbage collection to the concession on a competitive basis.

Following the results of the competition, an agreement between the investor and the local government was concluded, according to which the investor purchased equipment for garbage collection for the enterprise, and the local authorities provided the investor with benefits for paying land tax.

The investor was able to establish contacts with the enterprises that process sorted household waste and was able to make a profit from this. This made it possible to reduce the tariffs for the export of sorted household waste compared to non-sorted waste.

Thus, the conclusion of the concession agreement allowed the local authority to:

1) Shift the risks associated with the project implementation to a private investor.

2) Raise funds for the technical re-equipment of the enterprise engaged in garbage collection.

3) Assign responsibility to the investor in case of unsatisfactory performance of the obligations assumed by him.

The investor received a guaranteed volume of orders, as well as some guaranteed payments and the local budget. 


\section{Discussion}

The reasons that hinder the housing and communal services development are outdated material and technical base, imperfect management structure and a large share of state ownership.

Uncontrolled tariff policy and high production costs require new approaches to solving the problem of improving housing and communal services.

Attracting private investment in this area can not only reduce the financial burden on the budget, but also make housing and communal services profitable and energy efficient, and ensure compliance with the state norms and standards in the public services provision.

The concession of housing and communal services enterprises is one of the most effective forms of public-private cooperation in this sector.

\section{Conclusion}

Housing and communal services are one of the most important components in improving the living standard of citizens. Improving the housing and communal services sector efficiency requires its technical re-equipment. This can be achieved by attracting private investors to this industry, for which the state must create the necessary attractive conditions.

Public-private partnerships can become an important mechanism for solving many problems and contributing to the improvement of the innovation and investment climate in the housing and communal services sector.

\section{References}

1. Kiyomov Tukhtasinovich, Academicia: an international multidisciplinary research journal 11, 466-469 (2021). 10.5958/2249-7137.2021.00389.X.

2. Petro Kutsyk, Three Seas Economic Journal 1, 53-58 (2020). 10.30525/26615150/2020-3-9.

3. R. Izmailov, S. Baryshev, Gênero \& Direito 8, (2019). 10.22478/ufpb.21797137.2019v8n6.49207.

4. I. Sergeeva, O. Medvedeva, V. Vasilenok, Smart Technologies in Housing and Communal Services (2020). 10.2991/aebmr.k.200423.002.

5. V. Zharikov, E. Dmitrieva, Voprosy sovremennoj nauki i praktiki. Universitet imeni V.I. Vernadskogo, 084-088 (2017). 10.17277/voprosy.2017.04. pp.084-088.

6. V. Shitov, Organization of resource supply for housing and communal services (2020). $10.12737 / 1002912$.

7. D. Dzgoeva, L. Savelchev, Administrative Consulting, 154-162 (2021). 10.22394/1726-1139-2020-11-154-162.

8. R. Nurimbetov, T. Khasanov, A. Sultanov, Theoretical \& Applied Science 71, 66-71 (2019). 10.15863/TAS.2019.03.71.9.

9. O. Skripnik, IOP Conference Series: Earth and Environmental Science 90, 012142 (2017). 10.1088/1755-1315/90/1/012142. 